\title{
Contribution of photosynthetic sulfur bacteria to the alkaline phosphatase activity in anoxic aquatic ecosystems
}

\author{
L. Bañeras*, J. Rodriguez-Gonzalez, L. J. Garcia-Gil \\ Institute of Aquatic Ecology, University of Girona, Campus de Montilivi, E-17071 Girona, Spain
}

\begin{abstract}
We studied the relationship between photosynthetic sulfur bacteria and the amount and distribution of alkaline phosphatases in 2 small lakes in the Banyoles (NE Spain) karstic complex. The maximum alkaline phosphatase activity (APA) was found in the oxic/anoxic boundary layer (over $40 \mu \mathrm{M}$ pNP [p-nitrophenol] $\mathrm{h}^{-1}$ ). Multiple regression analysis of environmental data revealed a high correlation between bacterial pigments and particulate APA. A correlation coefficient $\left(r^{2}\right)$ of 0.550 was found in Lake Vilar when bacteriochlorophyll (Bchl) a was used as an independent variable. For Lake Sisó, the best correlation $\left(\mathrm{r}^{2}=0.577\right)$ was obtained when $\mathrm{Bchl} e, \mathrm{Bchl} d$ and chl a were used as independent variables. The specific alkaline phosphatase activities (SAPA) in the oxic layers were strongly influenced by the presence of photosynthetic bacteria. The induction of APA by 3 strains of photosynthetic bacteria isolated from the lakes was tested in the laboratory by measuring the response to incubation with different sources of organic phosphorus. Chromatium minus UdG2026, Chlorobium phaeobacteroides UdG6054 and Chlorobium limicola UdG6040 significantly increased the APA when incubated under phosphate limitation.
\end{abstract}

KEY WORDS: Alkaline phosphatase - Chromatium minus - Chlorobium spp. A Anoxic ecosystems Meromictic lakes - Phosphate deficiency

\section{INTRODUCTION}

Phosphorylated organic molecules provide an alternative source of phosphorus for aquatic microorganisms in environments with low phosphate concentrations. In certain conditions, growth of phytoplankton can be entirely supported by dissolved organic phosphorus (DOP) (Berman 1970, Aaronson \& Patni 1976). Although most organic $P$ compounds are not readily assimilated by organisms, uptake can be facilitated by cell-membrane associated enzymes (Karl \& Yanagi 1997). In such a situation the activity of hydrolytic enzymes such as phosphatases increases the availability of phosphate for the growing populations of algae (Jansson et al. 1988).

Severe phosphate limitation is not likely to occur in anoxic ecosystems, so phosphatase activities are not expected to increase the amount of phosphate avail-

\footnotetext{
•E-mail: catxo@morgat.udg.es
}

able to organisms growing in these layers. However, sharp phosphate gradients occur in well-stratified ecosystems, either at the thermo- or the chemocline level (Bañeras \& Garcia-Gil 1996, Overmann et al. 1996). As a consequence, photosynthetic sulfur bacteria and algae growing in such gradients shift from $\mathrm{P}$. repleted to P-depleted conditions in a few centimeters. In P-depleted conditions, organisms must have efficient phosphate uptake systems or be able to induce alkaline phosphatases in order to obtain phosphate from organic molecules.

Although several phosphatases exhibit maximum activity over a large range of $\mathrm{pH}$, the present study has focused on alkaline conditions, since alkaline phosphatases are understood to be inducible by the lack of inorganic phosphate and better correlate with phosphate limiting conditions (Cotner \& Wetzel 1991). Moreover, phosphatase activity may be analyzed together with the C:P molar ratio and P-limitation bioassays as an index of phosphorus deficiency (Berman 1970, Petterson 1980, Chróst \& Overbeck 1987. 
Boavida \& Marques 1995, Vrba et al. 1995). Alkaline phosphatases are produced both by bacteria and by algae but it is still unclear which group of microorganisms contributes the most to phosphatase activity in nature (Wetzel 1981, Currie et al. 1986).

In stratified lakes with a sulfide-containing hypolimnion, populations of phytoplankton and photosynthetic sulfur bacteria overlap in a narrow layer (Bañeras \& Garcia-Gil 1996, Gervais 1997). It is difficult to discern whether a single population is phosphate limited by using phosphatase activity as an indicator in these ecosystems. In a given ecosystem, however, the relative contribution of each group to phosphatase activity can be inferred from the relationship between the population dynamics and the phosphorus concentration.

Here we study the phosphate physiology of photosynthetic sulfur bacteria in natural conditions by measuring alkaline phosphatase activity (APA). In addition, the ability of these bacteria to grow with organic phosphorus as a sole phosphate source and the induction of alkaline phosphatases in these conditions have also been tested.

\section{MATERIAL AND METHODS}

Study area and sampling procedures. Lake Vilar (maximum depth $9.5 \mathrm{~m}$, area $10770 \mathrm{~m}^{2}$ ), which is meromictic, and holomictic Lake Sisó (maximum depth $6.3 \mathrm{~m}$, area $490 \mathrm{~m}^{2}$ ) are located in the Banyoles area (NE Spain). Both lakes remain thermally stratified from April to late September with thermoclines located at 4.5 and $1.5 \mathrm{~m}$ in Lakes Vilar and Sisó, respectively. The bottom water is permanently anoxic with a high concentration of sulfide and sulfur phototrophic bacteria (Montesinos et al. 1983, Guerrero et al. 1985, Bañeras \& Garcia-Gil 1996). Water samples were collected monthly from November 1995 to November 1996. Samples were obtained from the whole water column at 1 to $2 \mathrm{~m}$ intervals in the epi-and hypolimnia and at $20 \mathrm{~cm}$ intervals in the metalimnion.

Microorganisms and media used. Laboratory experiments were performed with the purple sulfur bacterium Chromatium minus UdG2026 and the green sulfur bacteria Chlorobium phaeobacteroides UdG 6054 and Chlorobium limicola UdG6040. All strains were isolated from the Banyoles area and identified according to morphological characteristics and pigment composition (Pfennig 1989). Cultures were maintained in Pfennig's mineral medium in the light and gradually shifted to phosphate-depleted conditions. Phosphate concentration of the basal medium was reduced to $30 \mu \mathrm{M}$ by successive inoculation of grown cultures in phosphate-free medium.
In order to estimate the utilization of organic phosphorus, the phosphate-limited cultures of the strains of photosynthetic bacteria were incubated with several organic phosphorus compounds until the stationary phase was reached. Cultures were incubated at saturating light intensities of $50 \mu \mathrm{E} \mathrm{m}^{-2} \mathrm{~s}^{-1}$ at the surface of the culture bottles, provided by a $100 \mathrm{~W}$ tungsten lamp. Sulfide was periodically added from a stock solution of $\mathrm{Na}_{2} \mathrm{~S}(100 \mathrm{mM})$ to a concentration of $1 \mathrm{mM}$ for green sulfur bacteria and $0.8 \mathrm{mM}$ for purple sulfur bacteria. The organic substrates used were glucose-1P (GLU), carbamoyl-P (CAR), ATP and RNA. The initial P concentrations were around $25 \mu \mathrm{M}$ in all treatments. Controls with no addition of phosphorus $\left(0 \mathrm{P}_{\mathrm{i}}\right)$ and with $25 \mu \mathrm{M}$ of inorganic phosphate $\left(25 \mathrm{P}_{\mathrm{i}}\right)$ were also incubated. In all the media used, the C:P molar ratio was higher than 500:1, confirming $P$ limitation. The stability of the organic complexes used in the incubation conditions was checked in sterile Pfennig's medium. Very little abiotic hydrolysis (less than $4 \%$ ) of GLU, ATP and RNA was observed during the $15 \mathrm{~d}$ incubation in these experimental conditions. CAR showed considerably higher degradation (up to $43 \%$ ) in the same period.

Chemical analyses. Water samples were filtered through a $0.45 \mu \mathrm{m}$ pore diameter membrane filter. Soluble reactive phosphorus (SRP) was determined from the filtered sample following the molybdate-ascorbic acid method described by Golterman et al. (1978). Sulfide was removed from the anoxic samples to avoid any interference in the phosphate determination. DOP and TP were measured as reactive phosphorus after the digestion of filtered and unfiltered samples. Temperature and digestion times were $135^{\circ} \mathrm{C}$ and $3 \mathrm{~h}$ to minimize the interference of sulfide in the phosphate assay.

Protein content was measured in methanol-extracted pellets by the Lowry method (Lowry et al. 1951). Pigments were determined by HPLC in acetone or methanol extracts according to Borrego \& Garcia-Gil (1994). Absorption spectra and retention times of eluted peaks were used to determine chlorophyll (chl) $a$ and bacteriochlorophylls (Bchl) $a, c, d$ and e. The area of the identified peaks with similar spectral properties was used to quantify the concentration of the pigments using the appropriate standards.

APAs were measured spectrophotometrically using p-nitrophenyl phosphate (pNPP Sigma 104 Phosphatase substrat) as a substrate according to the method of Huber \& Kidby (1984). The initial concentration of pNPP used for the incubation of samples was $250 \mu \mathrm{M}$ at $30^{\circ} \mathrm{C}, \mathrm{pH}=8.5$. External enzymatic activities were measured in samples filtered through a $0.45 \mu \mathrm{m}$ pore size membrane. The unfiltered samples were used for the determination of total activities. The influence of sulfide and sulfur on the phosphatase activity was 
checked using alkaline phosphatase from bovine intestine (Sigma P-3877). No significant effect of either sulfide or sulfur at concentrations below $1 \mathrm{mM}$ was observed on APA. Kinetic determinations of APA in water samples were made in a Spectronic MR3000 spectrophotometer using different concentrations of pNPP.

Samples were taken from Lake Vilar in July and assayed in the laboratory. Two samples, corresponding to the highest concentrations of chl a $\left(9.6 \mu \mathrm{g} \mathrm{l}^{-1}\right)$ and Bchl a $\left(223.9 \mathrm{\mu g} \mathrm{l}^{-1}\right)$ were analyzed. In the former $(4.0 \mathrm{~m})$ no sulfur bacteria were observed, whereas in the latter $(4.9 \mathrm{~m})$ a dense population of Chromatium minus was present.

\section{RESULTS}

\section{Dynamics of photosynthetic populations}

Photosynthetic populations, either algal or bacterial, showed a marked seasonality through the study. Phytoplankton had 2 population peaks in spring and late summer. Winter (from late October to March) was characterized by complete anoxia in the water column and the lack of algae in Lake Sisó (Fig. 1). Chl a was present in the epilimnion of Lake Vilar all the year round, with values ranging from 5 to $60 \mu \mathrm{g} \mathrm{I}^{-1}$. A steep peak of chl a, mainly due to Cryptomonas sp., was observed from May to September in the thermocline of both lakes

Different populations of sulfur photosynthetic bacteria were observed in the 2 lakes. Only 2 species of photosynthetic bacteria were identified in Lake Vilar, the purple bacterium Chromatium minus and the browncolored green sulfur bacterium Chlorobium phaeobacteroides. Little Bchl a was found between October and February; the maximum concentrations occurred during June and July and exceeded $2000 \mu \mathrm{g} \mathrm{l}^{-1}$. C. phaeobacteroides was present in the water column all the year round, with maximum densities between April and May. Photosynthetic populations preferentially distributed in the oxic-anoxic gradient during summer (Fig. 1).

In Lake Sisó, photosynthetic bacteria were present during the whole study period, reaching the highest densities from February to late August. Four main pigment composition groups were identified (Fig. 1). Chromatiaceae, quantified as concentration of Bchl $a_{\text {, }}$ were basically composed of 2 Chromatium species, C. minus and C. okenii, and Amoebobacter sp. The brown pigmented cells (containing Bchl e) were identified as Chlorobium phaeobacteroides and formed high population densities from March until late June. Two other bacteriochlorophylls (Bchl $c$ and Bchl $d$ ) were identified, which reveals the presence of greencolored green sulfur bacteria. Chlorobium limicola and the consortium 'Chlorochromatium aggregatum' were the most abundant organisms of green photosynthetic
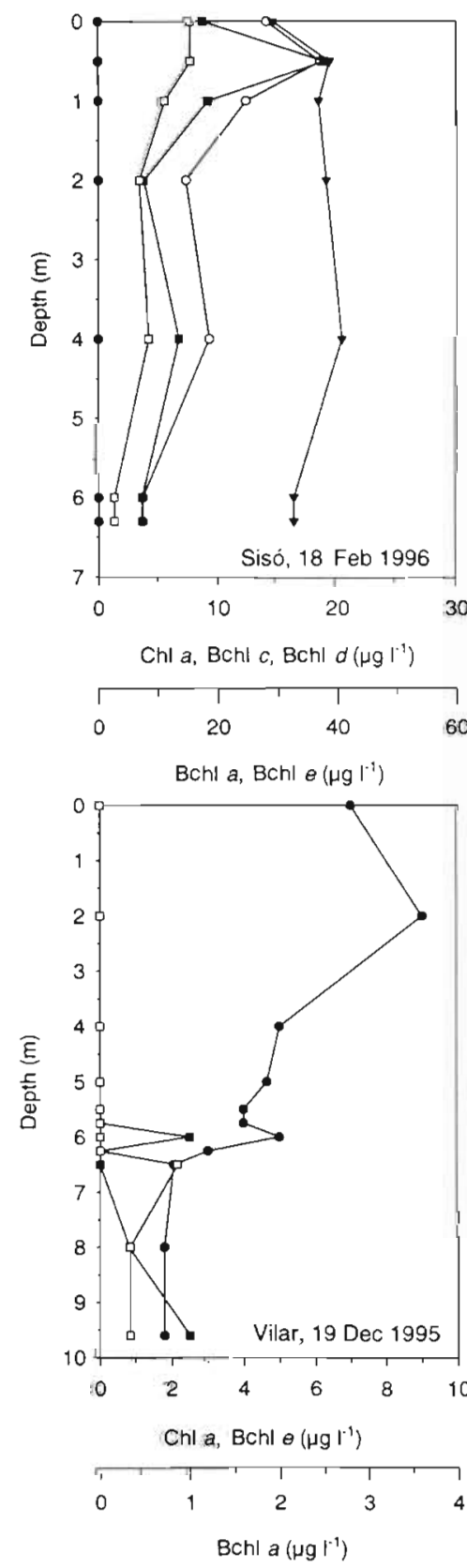

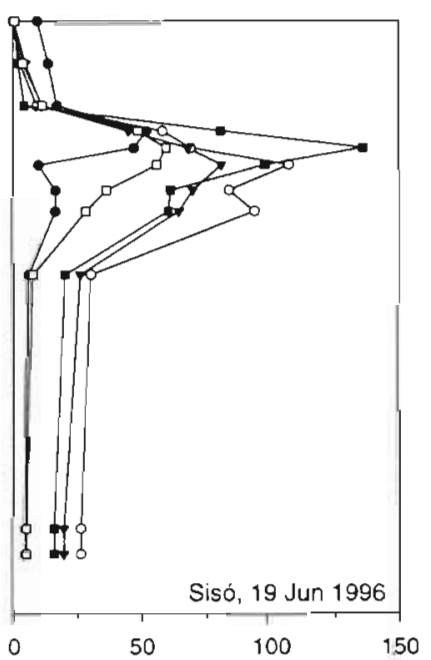

Chl a, Bchl $c$, Bchl $d\left\langle\left.\mu g\right|^{-1}\right\rangle$

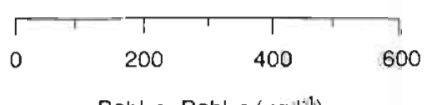

$\operatorname{Bchl} a, \operatorname{Bchl} e\left(\mu \mathrm{gl}^{-1}\right)$

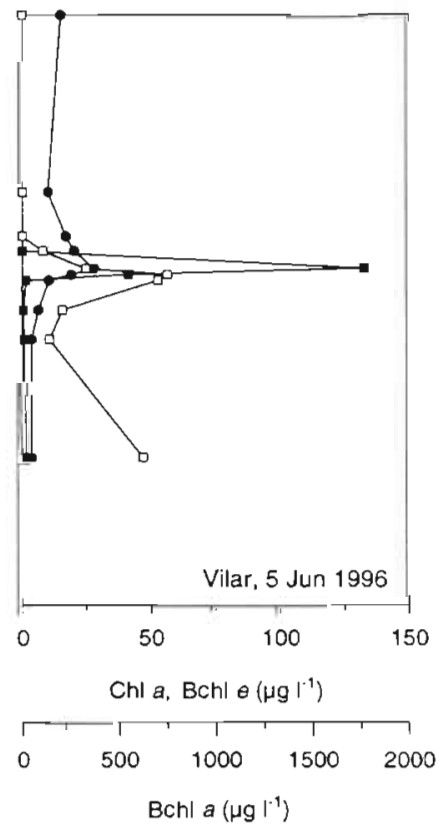

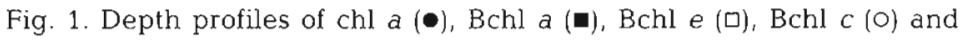
Bchl $d(\mathbf{v})$ concentrations in Lakes Vilar and Sisó. Common winter and summer situations are shown 
bacteria. Maximum densities of bacterial populations were found near the lake surface during winter and in the thermocline during summer.

\section{Alkaline phosphatase activity in lake samples}

In both water bodies (Lake Vilar and Lake Sisó) the maximum values of alkaline phosphatase during the stratification period were measured at the physicochemical gradients. During the mixing period, from October to March, APA was homogeneously distributed in the water column, and very low values $k 1 \mu \mathrm{M}$ pNPP $h^{-1}$ ) were obtained. Maximum activity in Lake Vilar was found between 4 and $5 \mathrm{~m}$ depth, reaching values above $40 \mu \mathrm{M}$ pNPP $\mathrm{h}^{-1}$, whereas in Lake Sisó activity was significantly lower and predominantly located at shallower depths, from 0.5 to $15 \mathrm{~m}$ (Fig. 2). External phosphatase activity represented from 5 to $80 \%$ of total activity. Despite this variability, the lowest external activity was found in the metalimnion.

In both ecosystems, the time-depth distribution of APA was similar to that of photosynthetic microorganisms. Multiple regression analysis gave a high correlation between particulate APA (retained in $0.45 \mu \mathrm{m}$ pore filters) and biomass indicators of planktonic phototrophs (Table 1). Bacterial populations, in particular those containing Bchl $a$, account for most APA varia-
Table 1. Multiple step-wise regression analysis of data from Lakes Vilar and Sisó. Particulate APA was taken as a dependent variable. Regression coefficients, $B$ ( $\mu \mathrm{mol}$ pNPP [ $\mu \mathrm{g}$ pigment $\left.\right|^{-1} \mathrm{~h}^{-1}$ ), and standardized coefficients, $\mathrm{Bn}$, are indicated. Values of $p>0.1$ are not included in the equation

\begin{tabular}{|c|c|c|c|c|}
\hline Lake & $\begin{array}{l}\text { Independent } \\
\text { variable }\end{array}$ & B & $\mathrm{Bn}$ & $\mathrm{p}$ \\
\hline Lake Vilar ${ }^{d}$ & Bchl a & 0.009 & 0.742 & 0.000 \\
\hline Lake Sisób & $\begin{array}{l}\text { Chl a } \\
\text { Bchl } e \\
\text { Bchl } d\end{array}$ & $\begin{array}{l}0.013 \\
0.004 \\
0.022\end{array}$ & $\begin{array}{l}0.413 \\
0.169 \\
0.464\end{array}$ & $\begin{array}{l}0.000 \\
0.054 \\
0.001\end{array}$ \\
\hline \multicolumn{5}{|c|}{$\begin{array}{l}{ }^{\mathrm{d}} \mathrm{n}=118, \mathrm{r}^{2}=0.550, \text { constant }=1.03\left(\mu \mathrm{M} \mathrm{pNP} \mathrm{h}^{-1}\right) \text {. } \\
\text { Not in the equation: chl } a, \text { Bchl } e\end{array}$} \\
\hline
\end{tabular}

tion in Lake Vilar, whereas in Lake Sisó the best correlation was found when Bchl $d$, Bchl e and chl a were included in the equation. For both lakes, external enzymatic activity was significantly correlated with chl a concentration, accounting for $38 \%(F=22.76, p<$ $0.001)$ and $20 \%(F=4.74, \mathrm{p}<0.05)$ of the total variation in Lakes Sisó and Vilar respectively.

The phosphatase kinetics of algal and bacterial populations were markedly different. Saturation of enzymatic activity occurred at a different pNPP concentra-

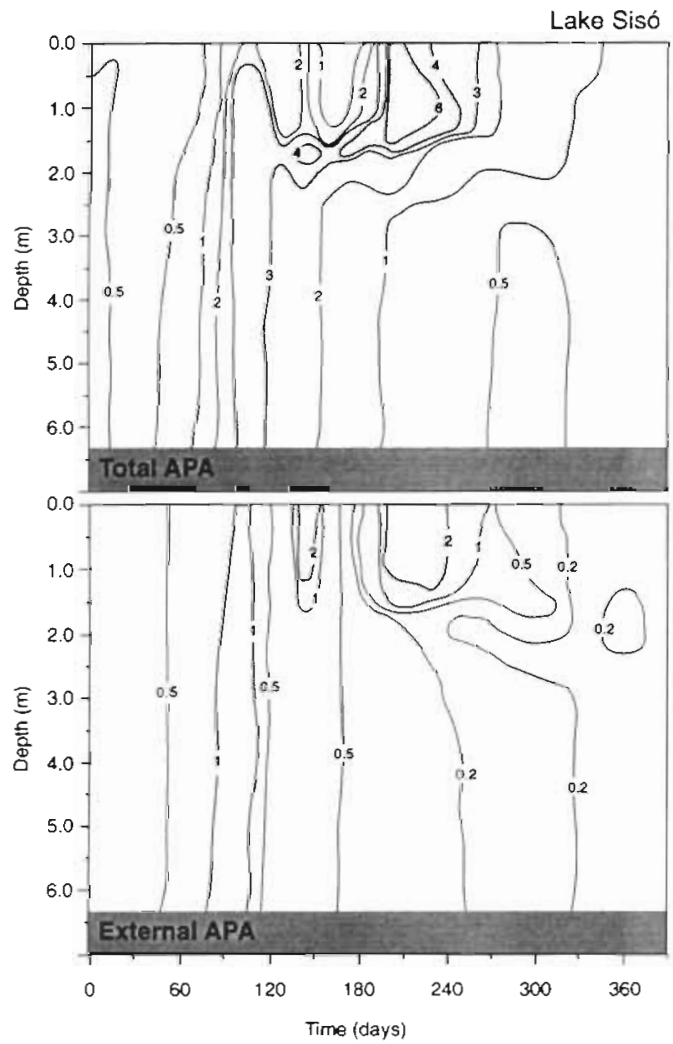

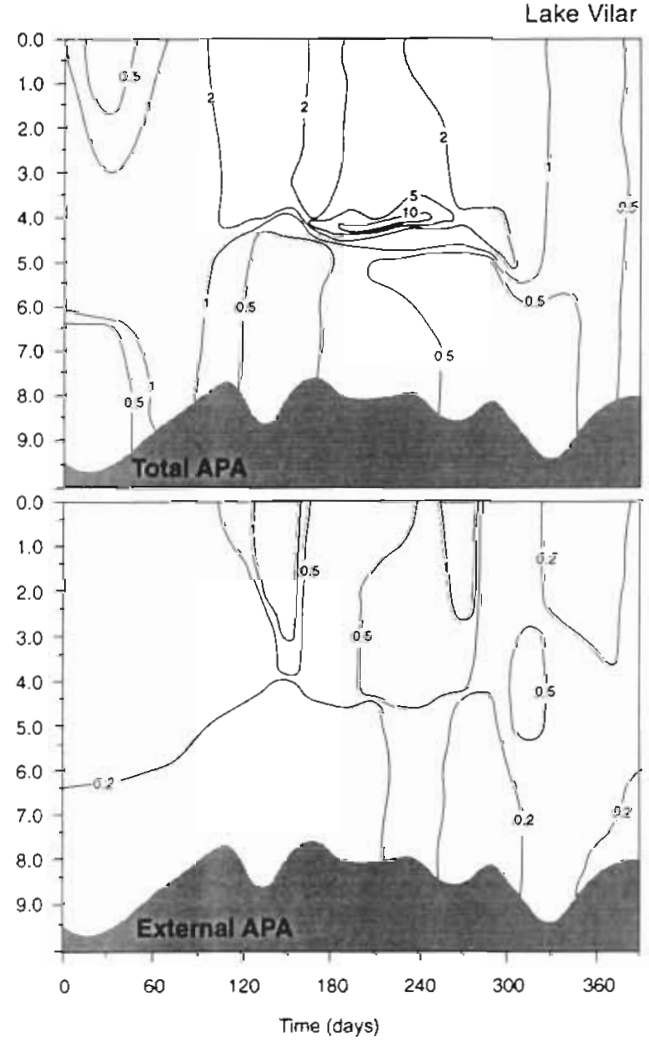

Fig. 2. Isopleths of total (upper panel) and soluble (lower panel) alkaline phosphatase activity (APA) $\left(\mu \mathrm{M} \mathrm{pNP} \mathrm{h}^{-1}\right)$ in Lakes Vílar and Sisó during the study period. Time scale in days from 1. November 1995 

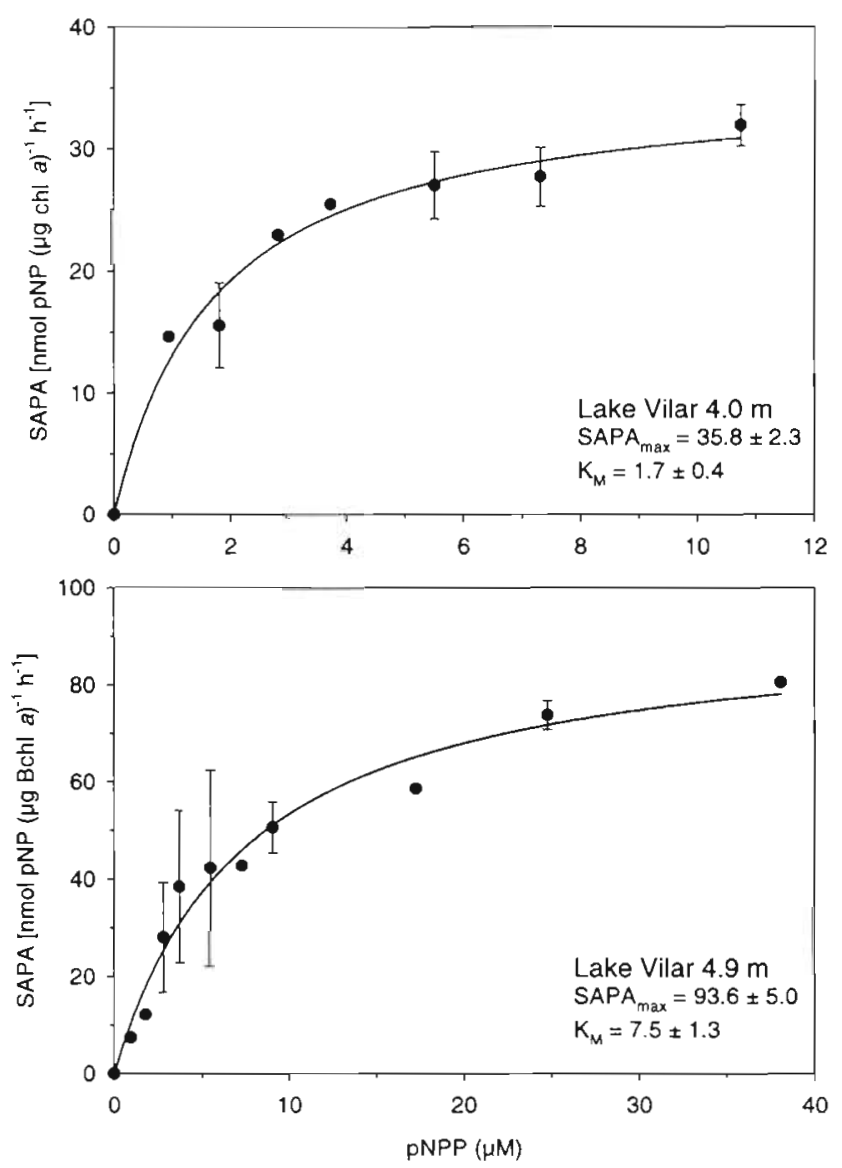

Fig. 3. Total specific alkaline phosphatase activity (SAPA) as a function of substrate concentration in samples from Lake Vilar. Best fits to a Michaelis-Menten saturation model and calculated parameters SAPA $A_{\max }$ and $K_{M}$ are indicated tion, resulting in a high disparity of the $K_{\mathrm{M}}$ value (Fig. 3). The lowest value of the phytoplankton population $(1.7 \pm 0.4 \mu \mathrm{M})$ suggested a higher affinity of epilimnetic phosphatases with pNPP than those of phototrophic bacteria $\left(K_{\mathrm{M}}=7.5 \pm 1.3 \mu \mathrm{M}\right)$. Although multiple regression analysis indicated that most of the APA in Lake Vilar was due to photosynthetic bacterial populations, kinetic data suggested a better adaptation of phytoplankton phosphatases to phosphorus-depleted conditions.

\section{Use of organic phosphorus by photosynthetic bacteria}

All the strains of sulfur phototrophic bacteria tested were able to grow with organic phosphorus substrates although differences in intracellular phosphorus were observed. The specific phosphorus content for each treatment was calculated as the particulate phosphorus per unit of protein at the end of the incubation (Table 2). The differences were significant when the species $(F=26.05, \mathrm{p}<0.001)$ or the incubation substrates $(F=2.86, \mathrm{p}<0.05)$ were used as comparison factors. Extremely low specific phosphorus content was obtained in Chromatium minus UdG2026 and Chlorobium phaeobacteroides UdG6054 when no phosphate was added. This indicates a high variation in the intracellular storage of $\mathrm{P}$ in these species. SAPA at the end of the incubation period was calculated in terms of pigment and protein concentration (Table 2) The latter value may be preferably used for compari-

Table 2. Specific phosphorus content and specific alkaline phosphatase activity (SAPA) at the end of incubation with different phosphorus substrates. $0 \mathrm{P}_{\mathrm{i}}$ : no addition of phosphorus; $25 \mathrm{P}_{1}: 25 \mu \mathrm{M}$ of inorganic phosphate; GLU: glucose-1P; CAR: carbamoyl-P

\begin{tabular}{|c|c|c|c|c|}
\hline Species & Treatment & $\begin{array}{c}\text { Specific P content } \\
\left.(\mu \mathrm{mol} \text { P [mg protein }]^{-1}\right)\end{array}$ & $\begin{array}{c}\text { SAPA } \\
\left(\mathrm{nmol} \mathrm{pNP}[\mu \mathrm{g} \mathrm{Bchl}]^{-1} \mathrm{~h}^{-1}\right)\end{array}$ & $\begin{array}{c}\text { SAPA } \\
\left.\text { (nmol pNP }[\mu \mathrm{g} \text { protein }]^{-1} \mathrm{~h}^{-1}\right)\end{array}$ \\
\hline $\begin{array}{l}\text { Chlorobium } \\
\text { limicola }\end{array}$ & $\begin{array}{l}O P_{i} \\
25 P_{i} \\
\text { GLU } \\
\text { CAR } \\
\text { ATP } \\
\text { RNA }\end{array}$ & $\begin{array}{l}0.95 \pm 0.32 \\
1.16 \pm 0.09 \\
1.41 \pm 0.07 \\
0.68 \pm 0.06 \\
0.90 \pm 0.09 \\
0.66 \pm 0.12\end{array}$ & $\begin{array}{l}5.29 \pm 1.31 \\
1.23 \pm 0.76 \\
3.03 \pm 1.04 \\
0.81 \pm 0.45 \\
0.69 \pm 0.09 \\
6.70 \pm 1.18\end{array}$ & $\begin{array}{l}1.61 \pm 1.48 \\
0.43 \pm 0.17 \\
0.95 \pm 0.43 \\
0.12 \pm 0.08 \\
0.09 \pm 0.06 \\
1.43 \pm 0.69\end{array}$ \\
\hline $\begin{array}{l}\text { Chromatium } \\
\text { minus }\end{array}$ & $\begin{array}{l}O P_{i} \\
25 P_{i} \\
\text { GLU } \\
\text { CAR } \\
\text { ATP } \\
\text { RNA }\end{array}$ & $\begin{array}{l}0.08 \pm 0.05 \\
0.42 \pm 0.05 \\
0.31 \pm 0.13 \\
0.32 \pm 0.10 \\
0.29 \pm 0.04 \\
0.58 \pm 0.07\end{array}$ & $\begin{array}{l}1.46 \pm 0.30 \\
1.43 \pm 0.46 \\
1.49 \pm 0.83 \\
1.49 \pm 0.19 \\
1.69 \pm 0.44 \\
1.89 \pm 0.57\end{array}$ & $\begin{array}{l}0.06 \pm 0.01 \\
0.04 \pm 0.01 \\
0.05 \pm 0.02 \\
0.05 \pm 0.03 \\
0.07 \pm 0.04 \\
0.09 \pm 0.04\end{array}$ \\
\hline $\begin{array}{l}\text { Chlorobium } \\
\text { phaeobacteroides }\end{array}$ & $\begin{array}{l}\text { OP, } \\
25 P_{1} \\
\text { GLU } \\
\text { CAR } \\
\text { ATP } \\
\text { RNA }\end{array}$ & $\begin{array}{l}0.32 \pm 0.12 \\
0.48 \pm 0.02 \\
0.39 \pm 0.07 \\
0.50 \pm 0.17 \\
0.37 \pm 0.05 \\
0.37 \pm 0.12\end{array}$ & $\begin{array}{l}8.65 \pm 1.77 \\
5.70 \pm 0.73 \\
6.18 \pm 0.48 \\
6.85 \pm 1.28 \\
9.43 \pm 2.88 \\
6.63 \pm 1.30\end{array}$ & $\begin{array}{l}0.12 \pm 0.07 \\
0.11 \pm 0.01 \\
0.10 \pm 0.02 \\
0.15 \pm 0.01 \\
0.12 \pm 0.03 \\
0.12 \pm 0.04\end{array}$ \\
\hline
\end{tabular}


son between species since the specific content of pigments differs greatly between these organisms. However, data from APA per unit pigment have been. included for comparison with field data

SAPA significantly increased from undetectable levels at the beginning of the experiment to values from 0.04 to $1.6 \mathrm{nmol} \mathrm{pNPP}$ ( $\mu \mathrm{g}$ protein $)^{-1} \mathrm{~h}^{-1}$ at the end of incubation. Higher values were recorded for Chlorobium limicola UdG6040. In this species, APA in OPi and RNA incubated cultures were significantly higher than those from other treatments. No significant differences were observed in Chromatium minus UdG2026 or Chlorobium phaeobacteroides UdG6054. No significant correlation was found between the specific content of phosphorus and SAPA in any of the species used.

\section{DISCUSSION}

The standardization of the alkaline phosphatase assay restricts enzymatic activity to a defined number of molecules and may result in substantial differences from the activity found in natural conditions. Moreover, it is difficult to compare data reported in the literature, owing to the wide variety of protocols (e.g. different temperatures, $\mathrm{pH}$ and substrates). Although APA is directly related to eutrophic conditions, it is not considered a good indicator of $\mathrm{P}$ deficiency in highly changing environments. Moreover, phosphate additions exceeding by far the in situ concentration are usually needed to obtain significant enzyme repression (Pick 1987).

Epilimnetic APA values found in Lake Vilar and Lake Sisó fall within the range of those reported for meso- and eutrophic lakes (Healey \& Hendzel 1980). However, the maximum values were found in physical and chemical gradients and are much higher than those reported in the literature. This may be the result of the biomass increase in the metalimnion as suggested by the significant relationship between APA and bacterial pigments reported above. In the meromictic Lake Vilar, the Chromatiaceae accounted for more than $70 \%$ of the particulate APA variation. The relative position of Chromatium minus, usually at the uppermost part of the oxic-anoxic gradient is likely to determine higher alkaline phosphatase induction levels. The half-saturation constant for phosphatase activity in C. minus enriched samples highly differed from that found for phytoplankton and was well above the in situ concentrations of DOP $(<3 \mu \mathrm{M})$. In Lake Sisó, 3 major photosynthetic populations (algae and 2 green phototrophic bacteria) contributed to $75 \%$ of the particulate APA variation. The differences observed between the 2 lakes may be due to the higher relative abundance of Chromatiaceae in Lake Vilar, positively affecting the correlation between Bchl a concentration and alkaline phosphatase in this ecosystem.

SAPA is thought to be inversely related to the trophic status and is considered a good indicator of phosphorus demand (Pick 1987). However, the calculation of specific activity may be hindered because vertical distribution of photosynthetic populations of algae and sulfur bacteria may overlap. As previously shown in this paper there is a significant contribution of each defined population to APA, making the use of specific activity as an indicator difficult. However, approximate ranges of specific activity may vary from 90 to $3 \mathrm{nmol}$ pNPP ( $\mu \mathrm{g}$ Bchl a $)^{-1} \mathrm{~h}^{-1}$ for Chromatiaceae-enriched samples and from 35 to $2 \mathrm{nmol}$ pNPP ( $\mu \mathrm{g} B \mathrm{Bhl} c_{r} d$ or $e)^{-1} \mathrm{~h}^{-1}$ for Chlorobiaceae-enriched samples, respectively. The reported values differ significantly from those obtained in P-depleted cultures in laboratory experiments and suggest the rejection of SAPA as a Pdeficiency indicator in gradient areas.

Different conclusions can be inferred from the epilimnetic data. In Lake Vilar, epilimnetic SAPA ranged from 0.03 to $0.30 \mu \mathrm{mol}$ pNPP ( $\mu \mathrm{g} \mathrm{chl} \mathrm{a})^{-1} \mathrm{~h}^{-1}$; the highest value was found during summer. Since Chromatium minus is the dominant photosynthetic species in Lake Vilar and shows an active phosphate uptake leading to particulate phosphorus accumulations within the chemocline (Bañeras \& Garcia-Gil 1996), epilimnetic SAPA was related to integrated Bchl $a$. The logarithmic correlation found (Fig. 4) strongly supports the hypothesis that sulfur photosynthetic bacteria directly affect the phosphorus availability of epilimnetic algal populations, thus partially decreasing the effects of eutrophication in the surface layers of the lake. Similar effects have been pointed out previously

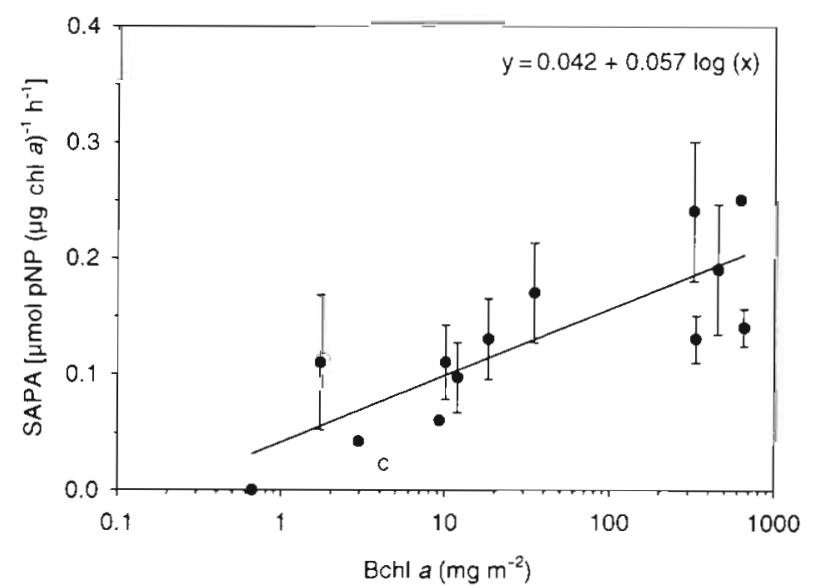

Fig. 4. Relation between the mean values of SAPA ( $\mu$ mol pNPP [ $\mu \mathrm{g} \mathrm{chl} \alpha]^{-1} \mathrm{~h}^{-1}$ ) in the epilimnion (from 0 to $4 \mathrm{~m}$ depth) and the integrated $B c h l a\left(\mathrm{mg} \mathrm{m}^{-2}\right)$ in Lake Vilar. Line: best logarithmic fit of data $\left(r^{2}=0.674\right)$ 
as the main reason for the enrichment of Cryptomonas $\mathrm{sp}$. in meromictic ecosystems (Garcia-Gil et al. 1993).

Although our results provide direct evidence of the use of organic compounds as a phosphate source by photosynthetic bacteria in laboratory conditions, it is difficult to confirm whether different substrates are directly assimilated by the microbial cells or externally hydrolyzed by induced enzymes. The assimilation of organic phosphate molecules by microorganisms has been shown to occur without enzymatic induction (Lugtenberg 1987). Furthermore, the ability of microorganisms to assimilate organic molecules such as glucose-P, glycerol-P or even larger molecules such as DNA, which can be used as a $\mathrm{P}$ source, is well known (Yagil 1987, Jørgensen \& Jacobsen 1996). The uptake of GLU, CAR and ATP can be indirectly inferred in Chlorobium limicola UdG6040 from the APA. The weaker enzymatic induction found in the previous treatments is directly caused by the presence of assimilable compounds, which do not generate any P limitation. These cultures are likely to increase AP induction when P-limited conditions occur. From our data it remains unclear whether or not Chromatium minus UdG 2026 and Chlorobium phaeobacteroides UdG 6054 can assimilate P-organic substrates. Both species completely depleted the added phosphate, so it is difficult to determine whether the induction and synthesis of alkaline phosphatase occurred before or after the exhaustion of phosphate.

All the species of photosynthetic sulfur bacteria tested responded to a critical situation such as the limitation of external phosphate by inducing the synthesis of alkaline phosphatases. $80 \%$ of the phosphatase activity remained in the particulate fraction. Induction of both alkaline and acidic phosphatases has previously been described in pure cultures of Chlorobium limicola and C. phaeobacteroides grown under different phosphate and light conditions (Wynne \& Bergstein Ben-Dan 1995).

From an ecological point of view, the induction of alkaline phosphatases together with the assimilation of organic substrates should improve the phosphorus availability under conditions of inorganic phosphate depletion in nature. However, a detailed characterization of the DOP in the studied ecosystems is needed to assess the importance of the alkaline hydrolysable fraction as a P source for photosynthetic bacteria. Phosphatase activity in the hydrolysis of the DOP pool in epilimnetic environments is not critical in many cases (Pick 1987, Bentzen \& Taylor 1991). In situ incubations with both soluble phosphate and organic molecules will be needed to corroborate the use of alkaline phosphatases in natural populations of photosynthetic sulfur bacteria, and to calculate their affinities for different phosphate sources.
Acknowledgements. We thank Anna M. Aymerich and Núria Cabezas for their valuable help in enzymatic determinations. This work was funded by a R+D project of the CICYT AMB 95-0323 granted to L.J.G.-G.

\section{LITERATURE CITED}

Aaronson S, Patni NJ (1976) The role of surface and extracellular phosphatase in the phosphorus requirement of Ochromonas. Limnol Oceanogr 21:838-845

Bañeras L, Garcia-Gil LJ (1996) Role of photosynthetic microbial populations in the phosphorus exchange through the oxic-anoxic boundary in a meromictic eutrophic lake. Arch Hydrobiol Spec Issues Adv Limnol 48:171-181

Bentzen E, Taylor WD (1991) Estimating organic P utilization by freshwater plankton using $\left[{ }^{32} \mathrm{P}\right] A \mathrm{ATP}$. J Plankton Res 13 : 1223-1238

Berman T (1970) Alkaline phosphatases and phosphorus availability in Lake Kinneret. Limnol Oceanogr 15: 663-674

Boavida MJ, Marques RT (1995) Low activity of alkaline phosphatase in two eutrophic reservoirs. Hydrobiologia 297: $11-16$

Borrego CM, Garcia-Gil LJ (1994) Separation of bacteriochlorophyll homologues from green photosynthetic sulfur bacteria by reversed phase HPLC. Photosynth Res 41: $157-163$

Chróst RJ, Overbeck J (1987) Kinetics of alkaline phosphatase activity and phosphorus availability for phytoplankton and bacterioplankton in lake Plußsee (north German eutrophic lake). Microb Ecol 13:229-248

Cotner JB, Wetzel R (1991) Bacterial phosphatases from different habitats in a small, hardwater lake. In: Chróst RJ (ed) Microbial enzymes in aquatic environments. Springer-Verlag, Berlin, p 187-205

Currie DJ, Bentzen E, Kalff J (1986) Does algal-bacterial phosphorus partitioning vary among lakes? A comparative study of orthophosphate uptake and alkaline phosphatase activity in freshwater. Can J Fish Aquat Sci 43:311-318

Garcia-Gil LJ, Borrego CM, Bañeras L, Abella CA (1993) Dynamics of phototrophic microbial populations in the chemocline of a meromictic basin of Lake Banyoles. Int Rev Ges Hydrobiol 78:283-294

Gervais F (1997) Diel vertical migration of Cryptomonas in the deep chlorophyl maximum of a eutrophic lake. J Plankton Res 19:533-550

Golterman HL, Clymo RS, Ohnstad MAM (eds) (1978) Methods for physical and chemical analysis of freshwaters. Blackwell, Oxford, p 111-117

Guerrero R, Montesinos E, Pedrós-Alió C, Esteve I, Mas J, van Gemerden H, Hofman PAG, Bakker JF (1985) Phototrophic sulfur bacteria in two Spanish lakes. Vertical distribution and limiting factors. Limnol Oceanogr 30: 919-931

Healey FP, Hendzel LL (1980) Physiological indicators of nutrient deficiency in lake phytoplankton. Can J Fish Aquat Sci 37:442-453

Huber AL, Kidby DK (1984) An examination of the factors involved in determining phosphatase activities in estuarine waters. 1: Analytical procedures. Hydrobiologia 111: 3-11

Jansson M, Olsson H, Pettersson K (1988) Phosphatases; origin, characteristics and function in lakes. Hydrobiologia 170:157-175

Jørgensen NO, Jacobsen CS (1996) Bacterial uptake and utilization of dissolved DNA. Aquat Microb Ecol 11:263-270 
Karl DM, Yanagi K (1997) Partial characterization of the dissolved organic phosphorus pool in the oligotrophic North Pacific Ocean. Limnol Oceanogr 42:1398-1405

Lowry OH, Rosenbrough NJ, Farr AL, Randall RJ (1951) Protein measurement with the Folin phenol reagent. J Biol Chem 193:265-275

Lugtenberg B (1987) The pho regulon in Eschenchia coli. In: Torriani-Gorini A, Rothman FG, Silver S, Wright A, Yagil E (eds) Phosphate metabolism and cellular regulation in microorganisms. American Society for Microbiology, Washington, DC, p 1-2

Montesinos E, Guerrero R, Abella CA, Esteve I (1983) Ecology and physiology of the competition for light between Chlorobium limicola and Chlorobium phaeobacteroides in natural habitats. Appl Environ Microbiol 46:1007-1016

Overmann J, Beatty JT, Hall KJ (1996) Purple sulfur bacteria control the growth of aerobic heterotrophic bacterioplankton in a meromictic salt lake. Appl Environ Microbiol 62: $3251-3258$

Petterson K (1980) Alkaline phosphatase activity and algal surplus phosphorus as phosphorus deficiency indicators in lake Erken. Arch Hydrcbiol 89:54-87

Pfennig N (1989) Green sulfur bacteria. In: Staley JT, Bryant

Editorial responsibility: Tom Fenchel,

Helsingør, Denmark
MP, Pfennig N, Holt GJ (eds) Bergey's manual of systematic bacteriology, $3 \mathrm{rd}$ edn. Williams and Wilkins, Baltimore, p 1682-1697

Pick FR (1987) Interpretations of alkaline phosphatase activity in lake Ontario. Can J Fish Aquat Sci 44:2087-2094

Vrba J, Vyhnálek V, Hejzlar J, Nedoma J (1995) Comparison of phosphorus deficiency indices during a spring phytoplankton bloom in a eutrophic reservoir. Freshwat Biol 33 73-81

Wetzel RG (1981) Long term dissolved and particulate alkaline phosphatase activity in a hardwater lake in relation to lake stability and phosphorus enrichments. Verh Int Verein Limnol 21:369-381

Wynne D, Bergstein Ben-Dan T (1995) The effect of light and phosphate concentrations on phosphatase activities of the photosynthetic bacterium Chlorobium spp. Can J Microbiol 41:278-283

Yagil E (1987) Introduction of phosphate and phosphorylated compounds in Escherichia coli. Introduction. In: TorrianiGorini A, Rothman FG, Silver S, Wright A, Yagil E (eds) Phosphate metabolism and cellular regulation in microorganisms. American Society for Microbiology, Washington, DC, p 143-144

Submitted: May 15, 1998; Accepted: October 20, 1998

Proofs received from author(s): June 7, 1999 